\title{
Preparation of Curcumin-Liposomes using pH-Driven Method to Enhance Stability and Encapsulation Efficiency
}

\section{Preparasi Liposom Kurkumin Menggunakan Metode Pengaturan pH untuk Meningkatkan Stabilitas dan Efisiensi Penjerapan}

\author{
Fransiska Christydira Sekaringtyas", Swasmi Purwajanti, Etik Mardliyati, Sri Ningsih \\ Center for Pharmaceutical and Medical Technology - Agency for the Assessment and Application of \\ Technology \\ Puspiptek Serpong, South Tangerang, Banten, Indonesia \\ *E-mail: fransiska.christydira@bppt.go.id
}

Diterima: 31 Januari 2020

Direvisi: 7 Februari 2020

Disetujui: 22 April 2020

\begin{abstract}
Curcumin, a hydrophobic polyphenol, derived from turmeric, has numerous pharmacological activities, including hepatoprotective, antioxidant, anti-inflammatory, antimicrobial, and anticarcinogenic. However, the therapeutic efficacy of curcumin is limited due to its poor oral bioavailability and high susceptibility to degradation. The poor oral bioavailability of curcumin has been attributed to its poor aqueous solubility and extensive first past metabolism. Curcumin dissolves in alkaline conditions but it is highly unstable undergoing rapid hydrolytic degradation in neutral or alkaline condition. To solve these problems, liposome-based encapsulation technology is applied to improve the bioavailability of curcumin. The existing method to prepare curcumin-liposome, thin-film method, is complex and usually required the use of organic solvents. In this study, $\mathrm{pH}$-driven method, an organic solvent-free and easily encapsulation technique utilizing the $\mathrm{pH}$-dependent solubility of curcumin was proposed to improve the stability and bioavailability. Curcumin-liposomes were prepared using phospholipon $90 \mathrm{H}$ and soya lecithin as phospholipid sources. The characterizations of curcuminliposomes include particle size, microstructure, encapsulation efficiency, infrared spectra, salt stability and storage stability. The particle size measured was $77.85 \pm 0.39 \mathrm{~nm}$. It was found that curcumin-liposomes prepared by the $\mathrm{pH}$-driven method was stable during storage for 30 days and gave encapsulation efficiency of $60.71 \pm 0.20 \%$, higher as compared to the ones prepared by thin-film method. In conclusion, $\mathrm{pH}$-driven is a promising method for the preparation of curcumin-liposomes to enhance stability and encapsulation efficiency.

Keywords: Curcumin; Liposome; Phospholipon 90 H; Soya lecithin; pH-driven method
\end{abstract}

\begin{abstract}
Abstrak
Kurkumin merupakan senyawa polifenol hidrofobik yang berasal dari kunyit, memiliki berbagai aktivitas farmakologi, antara lain sebagai hepatoprotektif, antioksidan, anti-inflamasi, antimikroba, dan antikanker. Namun, efektivitas terapi kurkumin terkendala bioavailabilitas oral kurkumin yang rendah dan rentan degradasi. Bioavailabilitas oral kurkumin yang rendah dikaitkan dengan buruknya kelarutan kurkumin dalam air dan tingginya efek metabolisme lintas pertama. Kurkumin larut dalam kondisi basa, namun menjadi tidak stabil dan terdegradasi dalam kondisi netral atau basa. Untuk mengatasi hal tersebut, digunakan teknologi enkapsulasi berbasis liposom yang dapat meningkatkan bioavailabilitas kurkumin. Metode terdahulu untuk membuat liposomal kurkumin adalah hidrasi lapis tipis, suatu metode yang kompleks dan memerlukan penggunaan pelarut organik. Dalam penelitian ini, digunakan metode pengaturan $\mathrm{pH}$, metode bebas pelarut organik dengan teknik enkapsulasi yang mudah berdasarkan ketergantungan kelarutan kurkumin pada pH, untuk meningkatkan stabilitas dan bioavailabilitas. Liposom kurkumin dipreparasi menggunakan phospholipon $90 \mathrm{H}$ dan soya lecithin sebagai fosfolipid. Karakterisasi liposom kurkumin meliputi ukuran partikel, struktur mikro, efisiensi penjerapan, spektrum inframerah, pengaruh kekuatan ionik terhadap stabilitas, serta stabilitas penyimpanan. Liposom kurkumin yang dihasilkan memiliki ukuran partikel 77,85 \pm 0,39 nm, stabil selama 30 hari penyimpanan, serta memiliki efisiensi penjerapan 60,71 $\pm 0,20 \%$, lebih tinggi dibandingkan dengan liposom kurkumin yang dipreparasi dengan metode hidrasi lapis tipis. Metode pengaturan pH merupakan metode yang menjanjikan dalam menyiapkan liposom kurkumin untuk meningkatkan stabilitas dan efisiensi penjerapan.
\end{abstract}

Kata kunci: Kurkumin; Liposom; Phospholipon 90 H; Soya lecithin; Metode pengaturan pH 


\section{INTRODUCTION}

Curcumin, a natural hydrophobic polyphenol derived from rhizomes of Curcuma longa Linn. (Zingiberaceae), has numerous medicinal benefit effects, including hepatoprotective, antioxidant, antimicrobial, anti-inflammatory, and anticarcinogenic activities. ${ }^{1}$ In spite of its efficacy, curcumin has not yet been approved as a therapeutic agent because of its low water solubility, low oral bioavailability, and high susceptibility to degradation., ${ }^{2,3}$ The several strategies have been performed to overcome these drawbacks. Numerous researches have reported on the use of various curcumin formulations toward improving the solubility as well as bioavailability of curcumin in aqueous systems, including nanoparticles, cyclodextrins, micelles, liposomes, and emulsions. $^{4}$ Among these approaches, encapsulating curcumin in liposomes has become one of the most promising methods because of its excellent compatibility of hydrophilic and hydrophobic molecules. Feng et al. have succeeded to entrap curcumin in liposomes and the result showed that liposomal curcumin suppressed pancreatic carcinoma growth in murine xenograft models and inhibited tumor angiogenesis. $^{3}$

Liposome is a spherical vesicle with phospholipid bilayer which can encapsulate both hydrophilic and hydrophobic components in the inner aqueous phase and incorporating them into the lipid bilayers, respectively. ${ }^{5,6}$ Curcumin-liposomes (CLs) have been prepared by the thin film method, as well as the properties and stability of these CLs have been widely studied by a number of groups. Nevertheless, the organic solvents used in this method is unacceptable for oral drug delivery. ${ }^{5,7}$ Recently, an organic solvent-free encapsulation, the $\mathrm{pH}$-driven method, was developed. This method is based on the deprotonation and dissolution of hydrophobic phytochemicals under alkaline conditions followed by neutralization to encapsulate the precipitated hydrophobic phytochemicals. ${ }^{7}$ The previous study showed that curcumin-liposomes which were formed using a single compound of phospholipid with $\mathrm{pH}$-driven method had the average diameter more than $200 \mathrm{~nm}(\sim 217.5 \mathrm{~nm})$ and encapsulation efficiency $\sim 62,8 \%$ with relatively intermediate stability which little bit precipitation was observed after the

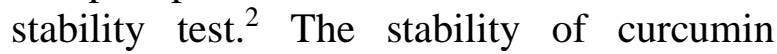
liposomes has potential to be improved by reducing the particle size and enhance the encapsulation efficiency.

In this research, curcumin was encapsulated in liposomes using two compounds of phospholipid with the $\mathrm{pH}$ driven method to improve its stability and encapsulation efficiency for the further aim as a hepatoprotective agent. The encapsulation efficiency and particle size of curcumin-liposomes formed by the $\mathrm{pH}$ driven method (PDM-CLs) were compared to curcumin-liposomes prepared using the thin film method (TFM-CLs). The stability study of the PDM-CLS and TFM-CLs after treatment with sodium chloride solution and storage for 30 days were also evaluated.

\section{METHODS}

Materials used in this research was Curcumin (Sigma Aldrich, $\geq 65 \%$, China). Phospholipon $90 \mathrm{H}$ [consisting mainly of phosphatidylcholine lysophosphatidylcholine (1.5\%), triglycerides $(0.3 \%)$ (Lipoid $\mathrm{GmbH}$, Ludwigshafen, Germany). Lecithin from Soya (grant from Zhejiang University, China). Methanol, chloroform and other reagents were all of the analytical grades.

\section{Preparation of curcumin-liposomes}

Curcumin-liposomes were prepared by the $\mathrm{pH}$-driven method and the thin film method. The phospholipid concentration was $10 \mathrm{mg} / \mathrm{mL}$, and the curcumin feed concentration was $0.4 \mathrm{mg} / \mathrm{mL}^{2}$ The phospholipid ratio (w/w) between phospholipon $90 \mathrm{H}$ and soya lecithin was 1:1.

\section{pH-driven method}

Curcumin and phospholipid were added to pure water grade II and stirred for 4 hours 
at room temperature. The $\mathrm{pH}$ of the solution was then adjusted to 12.0 with $4 \mathrm{M} \mathrm{NaOH}$. After stirring for 20 minutes, the $\mathrm{pH}$ of the solution was adjusted back to 5.3 with $4 \mathrm{M}$ $\mathrm{HCl}$. The curcumin-liposome suspension was further sonicated (on ice, 1 x 30 min) using a probe sonicator (Sonics, Vibra Cell, USA) and the PDM-CLs were then collected. ${ }^{2,7}$

\section{Thin-film method}

Briefly, curcumin and phospholipid were dissolved in chloroform and methanol (2:1 $\mathrm{v} / \mathrm{v})$, and the organic solvents were then evaporated using a rotary evaporator. The thin film was hydrated with phosphate buffer ( $\mathrm{pH}$ 7.4) and prepared the curcuminliposome suspension. The curcuminliposome suspension was further sonicated (on ice, 1 x $30 \mathrm{~min}$ ) using a probe sonicator (Sonic, Vibra Cell, USA) and the TFM-CLs were collected. ${ }^{1,3,8,9}$

\section{Characterization of curcumin-liposomes particle size}

The particle size of curcumin-liposomes (PDM-CLs and TFM-CLs) were measured using Partica LA-950V2 Laser Scattering Particle Size Analyzer (Horiba, Japan) with a fraction cell system. All data presented are the averages of at least triplicate measurements.

\section{Microstructure}

The microstructure of $\mathrm{pH}$-driven method curcumin-liposomes (PDM-CLs) was analyzed using a transmission electron microscope (TEM). Briefly, a drop of PDMCLs was placed onto a carbon-coated copper grid. After 3 minutes, the copper mesh grid was stained with acetic uranyl for 4 minutes and air-dried at room temperature after removing the excess liquid with filter paper. The sample was examined under a JEM-1400 transmission electron microscope (JEOL, Ltd., Tokyo, Japan) at a voltage of $120 \mathrm{kV}$.

\section{Encapsulation efficiency (EE)}

The curcumin-liposomes were centrifuged at 10,000 rpm for 30 min using a $\begin{array}{llll}\text { MIKRO } & 22 & \mathrm{R} & \text { centrifuge (Hettich }\end{array}$
Zentrifugen, Germany) to separate unencapsulated curcumin. The concentration of free curcumin (supernatant) was determined by UV-Vis spectrophotometry. At $421 \mathrm{~nm}$, the absorbance of free curcumin was calculated from the calibration curve, and encapsulation efficiency was then calculated by the following equation ${ }^{1,10}$ :

$E E(\%)=\frac{\text { total curcumin added }- \text { free curcumin }}{\text { total curcumin added }} \times 100 \%$

\section{Fourier transform infrared spectroscopy (FTIR)}

The infrared spectra of PDM-CLs, phospholipid and curcumin were separately obtained using Nicolet iS10 FTIR Spectrometer (Thermo Fisher Scientific Inc, Madison, USA). The samples were placed on Smart iTRTM Attenuated Total Reflectance (ATR) accessory composed of diamond crystal as sample handling technique at a controlled ambient temperature $\left(25^{\circ} \mathrm{C}\right)$. The samples were scanned by an infrared spectrometer over the range from 4000 to $400 \mathrm{~cm}^{-1}$. 11

\section{Stability study \\ Salt stability}

The influence of ionic strength on the stabilities of the PDM-CLs and TFM-CLs was determined by treatment with several concentrations of $\mathrm{NaCl}$ solution $(10,50,100$, 200,500 , and $1000 \mathrm{mM}$ ) for 1 hour at room temperature. ${ }^{2}$ The appearance of the samples was observed after incubation for 1 hour in room temperature and after 3 days at $4^{\circ} \mathrm{C}$.

\section{Storage stability}

To evaluate the shelf life, the PDM-CLs and TFM-CLs were stored in a container at $4^{\circ} \mathrm{C} .^{2}$ Changes in the particle size and encapsulation efficiency were investigated every five days during storage for one month.

\section{RESULT AND DISCUSSION}

\section{Preparation and characterization of PDM- CLs}

The process for preparing $\mathrm{pH}$-driven method curcumin liposomes (PDM-CLs) is illustrated in Figure 1. The amounts of 
curcumin and phospholipid were mixed to pure water grade II and agitated for 4 hours at room temperature. After agitation for 4 hours, the phospholipid was fully dissolved and had self-assembled into liposomes with an average diameter of $11.58 \mu \mathrm{m}$. The encapsulation efficiency (EE) of curcumin into liposome was $12.91 \% \pm 0.26 \%$, which indicate the liposomes had been prepared by dissolving the phospholipid in water and the curcumin was loaded into liposomes but with low EE. The liposomes solution was then adjusted to $\mathrm{pH} 12.0$ using $4 \mathrm{M} \mathrm{NaOH}$ to dissolve curcumin. Under alkaline conditions, the amount of curcumin loaded into liposomes decreased as well as deprotonated curcumin become unstable, deep red in color, and water-soluble. ${ }^{2}$ This observation prompted us to examine the stability of curcumin-liposomes at $\mathrm{pH}$ 12.0. In the previous study, the curcumin was completely dissolved after 20 minutes, indicating that decomposition was negligible, thus the curcumin-liposomes could be safely prepared at $\mathrm{pH} 12.0 .^{7}$ After 20 minutes, the solution was adjusted back to $\mathrm{pH} 5.3$ using 4 $\mathrm{M} \mathrm{HCl}$, and the PDM-CLs were collected. The average diameter and EE of the PDMCLs were $77.85 \mathrm{~nm} \pm 0.39 \mathrm{~nm}$ and $60.71 \% \pm$ $0.20 \%$, respectively.

There are two noticeable phenomena associated with the $\mathrm{pH}$-driven method. First, the particle size of the liposomes decreased dramatically from $11.58 \mu \mathrm{m}$ to $77.85 \mathrm{~nm}$ after adjusting the $\mathrm{pH}$. This reduction diameter might due to the osmotic force generated by the ionic gradient across the membrane and lead to the evacuation of water from the inner core of the liposome. ${ }^{7,12}$ Second, the EE of the curcumin-liposomes increased from $12.91 \%$ to $60.71 \%$ in the $\mathrm{pH}$ driven process. This phenomenon can be explained by the different states of curcumin. Curcumin is insoluble (hydrophobic) at $\mathrm{pH}$ 5.3 and soluble (hydrophilic) at $\mathrm{pH}$ 12.0. When curcumin and phospholipid are mixed in water at low $\mathrm{pH}$, the hydrophobic form of curcumin is not in contact with the liposomal membrane. ${ }^{2}$ During the $\mathrm{pH}$-driven process, curcumin was dissolved in water at $\mathrm{pH} 12.0$ and made full contact with the liposomal membrane. When the $\mathrm{pH}$ decreased to 5.3, the curcumin was transformed from the hydrophilic form to the hydrophobic form and diffused into the liposomal membrane driven by hydrophobic forces. ${ }^{2}$

The apparent microstructure of curcuminliposomes using TEM (Figure 2) showed that the PDM-CLs were spherical define shapes and multilamellar vesicles. In $\mathrm{pH}$-driven method, the phospholipid is dissolved in water and self-assembles into liposomes. Since there is no ethanol present in the preparation process, the phospholipid molecules do not form bilayer fragments. ${ }^{6,12}$ As a result, the liposomes prepared by the $\mathrm{pH}$-driven method are more likely to assemble into multilamellar membrane structures. $^{13}$

FTIR was examined to further verify

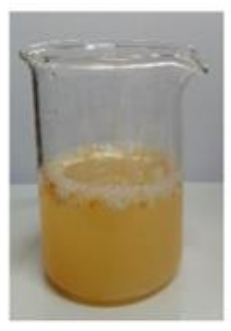

$\mathrm{pH} 7.0$

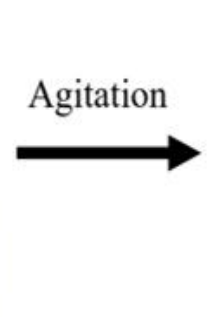

pH 5.3

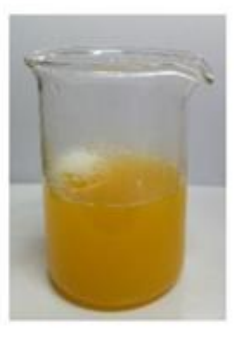

EE: $12.91 \%$

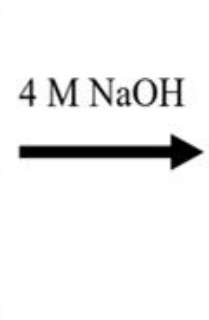

pH 12.0

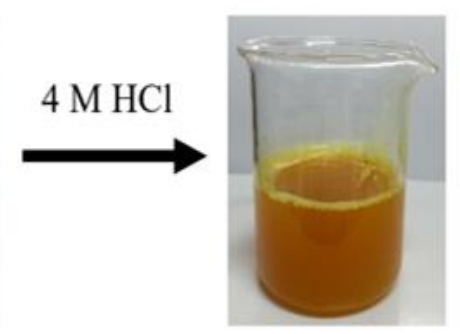

$\mathrm{pH} 5.3$

EE: $60.71 \%$

Figure 1. The schematic process of $\mathbf{p H}$-driven method curcumin-liposomes 
whether curcumin was successfully incorporated into the liposomes. The FTIR spectrum of curcumin powder, phospholipid and PDM-CLs are presented in Figure 3.

Curcumin exhibited its signature peaks at $3505 \mathrm{~cm}^{-1}$ (phenolic $\mathrm{O}-\mathrm{H}$ stretching vibration), $1626 \mathrm{~cm}^{-1}$ (aromatic moiety $\mathrm{C}=\mathrm{C}$ stretching), $1599 \mathrm{~cm}^{-1}$ (benzene ring stretching vibration), $1503 \mathrm{~cm}^{-1}(\mathrm{C}=\mathrm{O}$ and $\mathrm{C}=\mathrm{C}$ vibrations), $1425 \mathrm{~cm}^{-1}$ (olefinic $\mathrm{C}-\mathrm{H}$ bending vibration), $1270 \mathrm{~cm}^{-1}$ (aromatic C-
O stretching vibration), $1024 \mathrm{~cm}^{-1}$ (C-O-C stretching vibration). ${ }^{14}$ On the other hand, the phospholipid showed their typical peaks at 2358 and $2341 \mathrm{~cm}^{-1}$ (the $\mathrm{CH}_{2}$ stretching vibration), $1735 \mathrm{~cm}^{-1}$ (symmetrical $\mathrm{C}=\mathrm{O}$ stretching vibration), $1649 \mathrm{~cm}^{-1}$ (water scissoring band) and $1195 \mathrm{~cm}^{-1}\left(\mathrm{PO}_{4}\right.$ antisymmetric stretching band). ${ }^{15}$

When curcumin was incorporated into the liposomes, the peak location and shape were similar to the phospholipids at

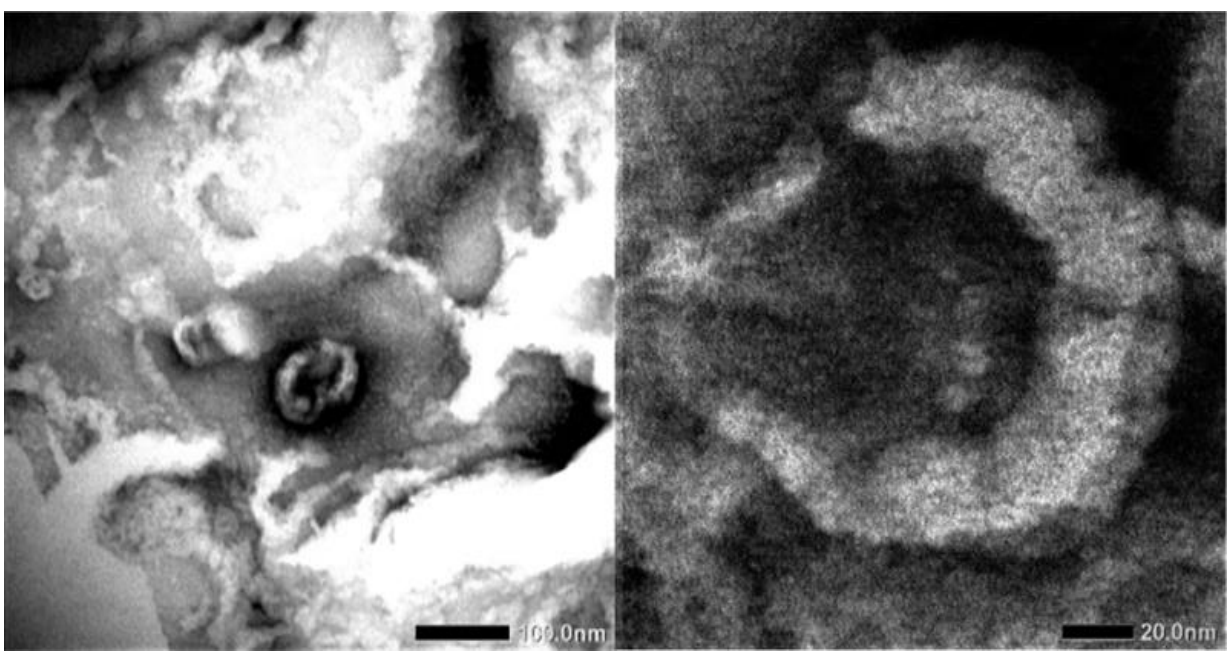

Figure 2. TEM micrograph of PDM-CLs

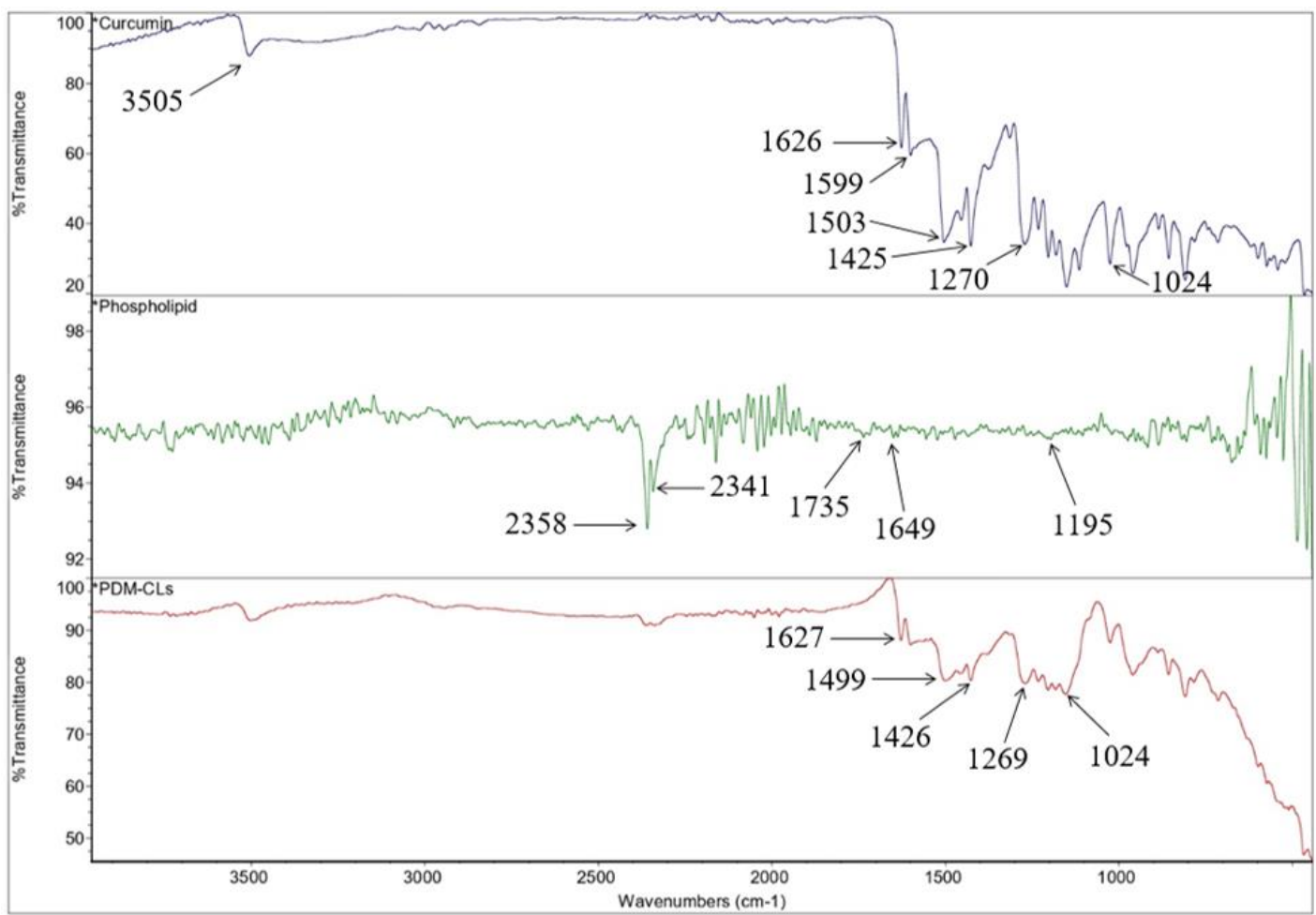

Figure 3. The FTIR spectrum of curcumin powder (A); phospholipid (B); and PDM-CLs (C) 
$2358 \mathrm{~cm}^{-1}$ and $2341 \mathrm{~cm}^{-1}\left(\mathrm{CH}_{2}\right.$ vibration absorption), $1735 \mathrm{~cm}^{-1}$ (symmetrical $\mathrm{C}=\mathrm{O}$ stretching vibration absorption) and 1195 $\mathrm{cm}^{-1}$ ( $\mathrm{PO}_{4}$ antisymmetric stretching bands).

Meanwhile, the PDM-CLs represented peaks at $1627 \mathrm{~cm}^{-1}$ (aromatic moiety $\mathrm{C}=\mathrm{C}$ stretching $), 1499 \mathrm{~cm}^{-1}(\mathrm{C}=\mathrm{O}$ and $\mathrm{C}=\mathrm{C}$ vibrations), $1426 \mathrm{~cm}^{-1}$ (olefinic $\mathrm{C}-\mathrm{H}$ bending vibration), $1269 \mathrm{~cm}^{-1}$ (aromatic C$\mathrm{O}$ stretching vibration) and $1024 \mathrm{~cm}^{-1}(\mathrm{C}$ $\mathrm{O}-\mathrm{C}$ stretching vibration), which are the characteristic peaks of curcumin and indicated the existence of curcumin in the liposome. ${ }^{11}$ The peaks of curcumin encapsulated in liposomes were shifted from 1503 to $1499 \mathrm{~cm}^{-1}$ which exhibited an interaction between curcumin and phospholipid, as well as the disappearance peak of $3505 \mathrm{~cm}^{-1}$ in PDM-CLs spectrum indicated the interaction between the phenolic $-\mathrm{OH}$ of curcumin and phospholipid, most likely through hydrogen bonding. ${ }^{11,16}$ The absorption of curcumin main peak's wane and the peaks shifted when curcumin encapsulated in liposomes suggesting that the curcumin molecules were located inside the liposomes, consequently, the signature spectrum of curcumin was hidden. ${ }^{16}$

\section{Stability of PDM-CLs}

The average diameter and encapsulation efficiency (EE) of curcuminliposomes were measured every five days during storage for one month at $4{ }^{\circ} \mathrm{C}$ (Table 1 and Figure 4). The TFM-CLs were unstable during storage and displayed particle swelling, and there was leakage of curcumin which was marked by the precipitation after storage for 30 days (Figure 5A). The amount of curcumin encapsulated by the TFM-CLs decreased from $43.64 \%$ to $24.94 \%$, and the particle size increased dramatically from $88.82 \mathrm{~nm}$ to $7557.58 \mathrm{~nm}$. This phenomenon is probably caused by the heating during the process of hydrating a thin film which makes curcumin becomes unstable and precipitates after several days of storage. On the other hand, the PDM-CLs were relatively stable during storage for 30 days and there was not any precipitation occurred (Figure 5B). The amount of curcumin encapsulated by the PDM-CLs decreased slightly from $60.71 \%$ to $51.78 \%$, as well as the particle size increased from $77.85 \mathrm{~nm}$ to $200.66 \mathrm{~nm}$ after 30 days at $4^{\circ} \mathrm{C}$. These results indicate that PDM-CLs are stable during storage at $4^{\circ} \mathrm{C}$ with little leakage of curcumin.

The influence of ionic strength on the stability of the PDM-CLs and TFM-CLs was evaluated by observing the visual appearance of curcumin-liposomes after incubation with different concentration of $\mathrm{NaCl}$ for 1 hour at room temperature and after storage for 3 days at $4^{\circ} \mathrm{C}$ (Figure 6). Although $\mathrm{NaCl}$ was produced during the preparation of PDM-CLs, it presented a relatively PDM-CLs, it presented a relatively low concentration and did not influence the results of the stability study. ${ }^{2}$

Table 1. The result of average diameter and encapsulation efficiency of PDM-CLs and TFMCLs during storage for 30 days at $4^{\circ} \mathrm{C}$

\begin{tabular}{lcccc}
\hline $\begin{array}{l}\text { Storage } \\
\text { Time } \\
(\text { day) }\end{array}$ & \multicolumn{2}{c}{ Average Diameter $(\mathbf{n m})$} & \multicolumn{2}{c}{ Encapsulation Efficiency (\%) } \\
\cline { 2 - 5 } & PDM-CLs & TFM-CLs & PDM-CLs & TFM-CLs \\
\hline 0 & $77.85 \pm 0.39$ & $88.82 \pm 0.12$ & $60.71 \pm 0.20$ & $43.64 \pm 2.59$ \\
5 & $84.50 \pm 0.21$ & $83.11 \pm 1.30$ & $52.79 \pm 2.40$ & $36.37 \pm 2.55$ \\
10 & $88.63 \pm 0.24$ & $398.72 \pm 0.53$ & $53.31 \pm 1.22$ & $35.33 \pm 2.63$ \\
15 & $200.30 \pm 0.23$ & $620.15 \pm 1.26$ & $50.64 \pm 2.05$ & $34.45 \pm 0.52$ \\
20 & $200.71 \pm 0.55$ & $616.14 \pm 1.68$ & $55.66 \pm 1.27$ & $35.56 \pm 2.12$ \\
25 & $199.83 \pm 0.08$ & $7305.25 \pm 108.91$ & $52.66 \pm 0.54$ & $31.58 \pm 1.33$ \\
30 & $200.66 \pm 0.31$ & $7557.58 \pm 240.88$ & $51.78 \pm 0.59$ & $24.94 \pm 3.32$ \\
\hline
\end{tabular}



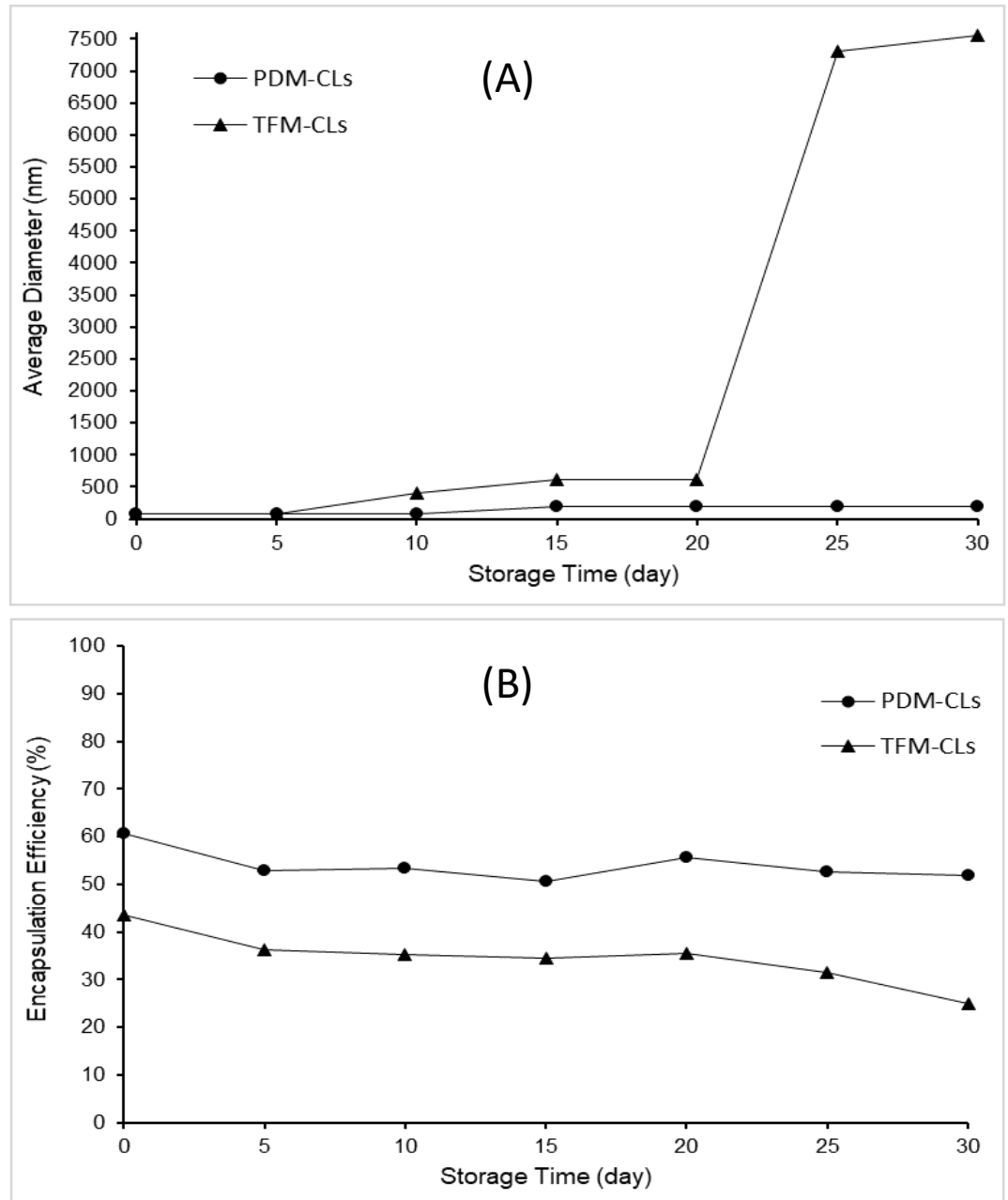

Figure 4. The changes in average diameter (A) and encapsulation efficiency (B) of PDM-CLs and TFMCLs during storage for 30 days at $4^{\circ} \mathrm{C}$
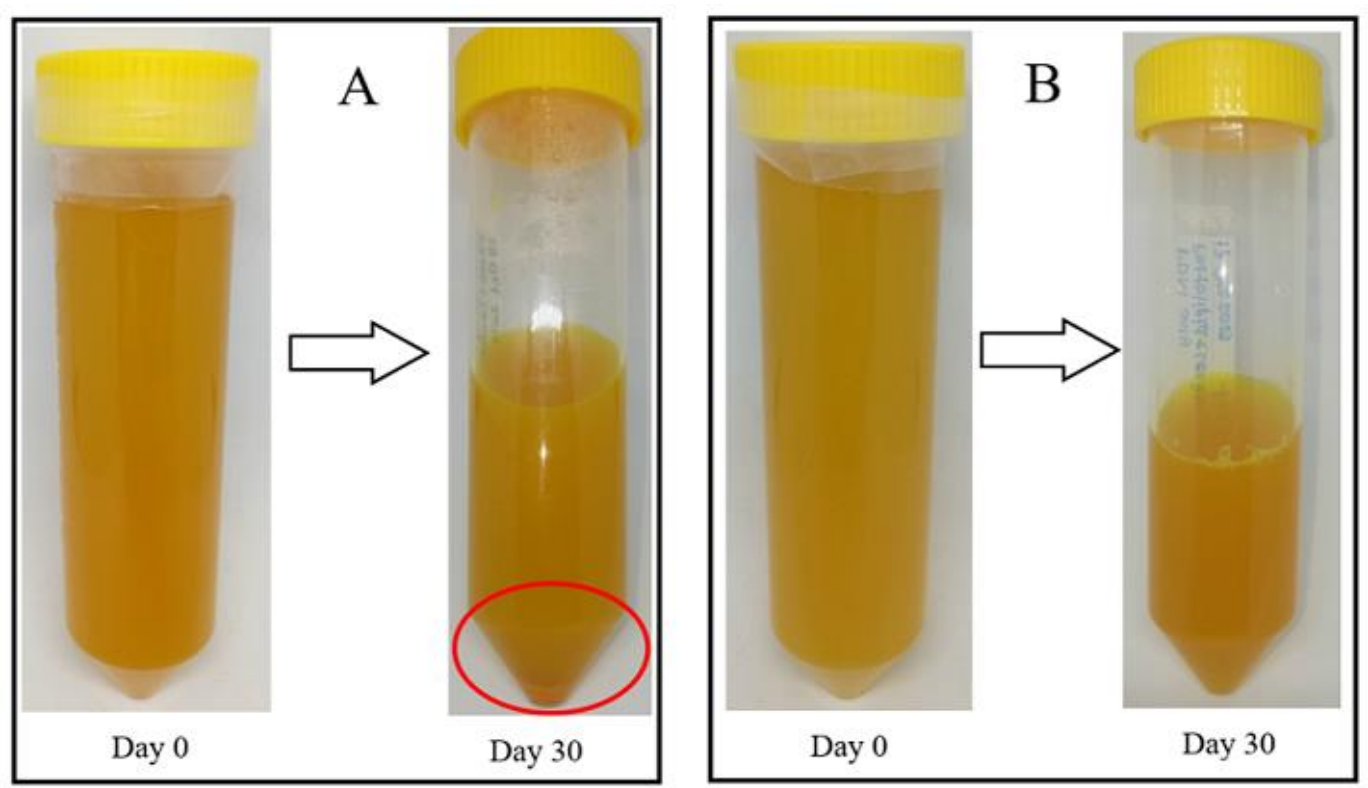

Figure 5. The visual appearance of TFM-CLs (A) and PDM-CLs (B) after storage for 30 days at $4^{\circ} \mathrm{C}$ 
The transparency of the PDM-CLs decreased after treatment with $500 \mathrm{mM}$ and $1000 \mathrm{mM} \mathrm{NaCl}$ for 1 hour until 3 days. Moreover, the TFM-CLs also become turbid after treatment with $500 \mathrm{mM}$ and $1000 \mathrm{mM} \mathrm{NaCl}$ for 1 hour, and some precipitation were observed at high concentration of $\mathrm{NaCl}(>200 \mathrm{mM})$ after 3 days treatment. These results indicate that TFM-CLs are sensitive to changes in ionic strength. ${ }^{9}$ On the other hand, PDM-CLs have intermediate stability at low concentration of $\mathrm{NaCl}(\leq 200 \mathrm{mM})$ and less stable at higher concentration of $\mathrm{NaCl}$ solution (> $200 \mathrm{mM}$ ).

When the ionic gradient across the liposomal membrane is too high, an osmotic force is generated and water flows out of the liposomes to compensate for the high external ion concentration. ${ }^{17}$ This causes a reduction in particle size until the maximum compaction of the bilayer is reached. ${ }^{2}$ This phenomenon was not observed in the PDM-CLs because it had already occurred during liposome formation. Liposomal dispersions are thermodynamically unstable. According to the extended Derjaguin-Landau-VerwyOverbeek theory, there are two main repulsive forces, the electrostatic force and hydration force. $^{2,7}$ At relatively low concentration of $\mathrm{NaCl}(<200 \mathrm{mM})$, the electrostatic and hydration forces were sufficiently strong to overcome the attractive force, thus all of the two liposomal formulations were stable. At relatively high concentration of $\mathrm{NaCl}$ (> $500 \mathrm{mM}$ ), the counter-ions in $\mathrm{NaCl}$ screen the electrostatic repulsive force acting between the particles. ${ }^{17}$ In this condition, the stability of liposomes decreases which the PDM-CLs were more stable than TFMCLs.

Based on the result of this research, it observed that the use of two compounds phospholipid could reduce the particle size of curcumin-liposomes which made it stable during storage compared to the previous study which only used a single compound. The smaller of liposomal particle size will be resulting in better stability.

On the other hand, the use of two compounds of phospholipid does not
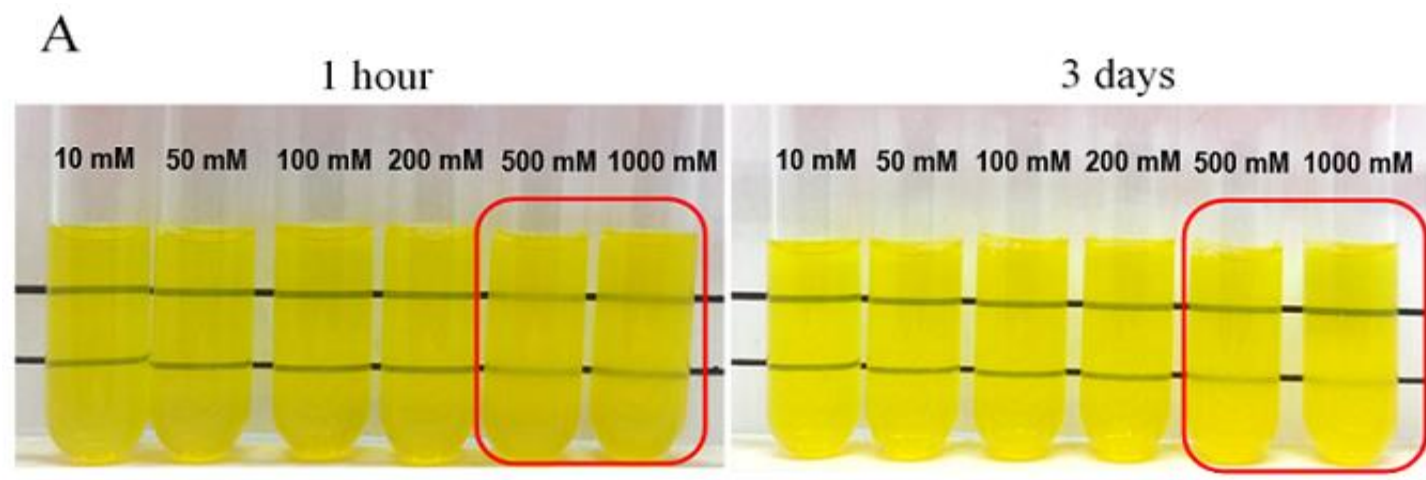

B

1 hour

3 days

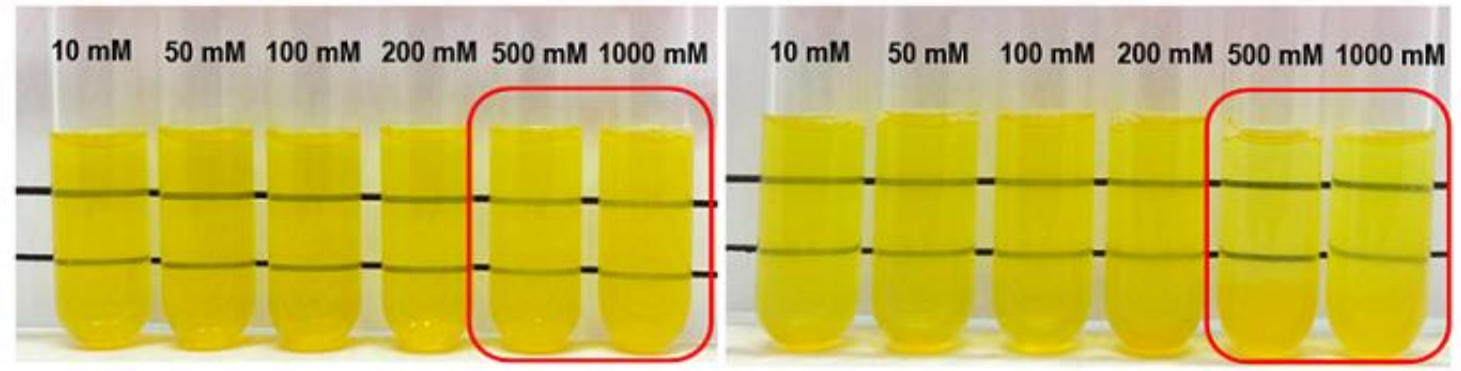

Figure 6. Effect of $\mathrm{NaCl}$ concentration on the visual transparency of PDM-CLs (A) and TFM-CLs (B) after storage for 1 hour at room temperature and 3 days at $4^{\circ} \mathrm{C}$ 
increase the encapsulation efficiency of curcumin-liposomes. The result showed that encapsulation efficiency still stayed at around $60 \%$ as same as the uses of a single compound phospholipid. This probably depends on the type of phospholipid is used which will affect the character of the hydrophobic layer being occupied by curcumin.

\section{CONCLUSION}

The curcumin-liposomes could be prepared using the $\mathrm{pH}$-driven method which based on the self-assembly behavior of phospholipid in water and the diffusion of curcumin into liposomal membranes by hydrophobic forces. The result showed that the PDM-CLs with two compounds of phospholipid have good encapsulation efficiency, nano-scale liposomal particle size, and high stability during storage. The $\mathrm{pH}$-driven method is a promising method to prepare curcumin-liposomes with organic solvent-free, simple equipment and easy to control.

\section{ACKNOWLEDGEMENT}

The authors thank the materials support from Zhejiang University under the joint lab on biotechnology Agency for The Assessment and Application of Technology (BPPT) - Zhejiang University scheme.

\section{REFERENCES}

1. Konatham $S$, Nyathani HK, Bonepally CR, Yeannameneni PK, Aukunuru J. Liposomal delivery of curcumin to liver. Turkish Journal of Pharmaceutical Sciences. 2010;7(2):89-98.

2. Cheng C, Peng S, Li Z, Zou L, Liu W, Liu C. Improved bioavailability of curcumin in liposomes prepared using a $\mathrm{pH}$-driven, organic solvent-free, easily scalable process. Royal Society of Chemistry Advances. 2017;7(42):2597886.

3. Feng $\mathrm{T}$, Wei $\mathrm{Y}$, Lee RJ, Zhao L. Liposomal curcumin and its application in cancer. International Journal of Nanomedicine. 2017;12:6027-44.

4. Lu Y, Ding N, Yang C, Huang L, Liu J,
Xiang G. Preparation and in vitro evaluation of a folate-linked liposomal curcumin formulation. Journal of Liposome Research. 2012;22(2):110-9.

5. He H, Lu Y, Qi J, Zhu Q, Chen Z, Wu W. Adapting liposomes for oral drug delivery. Acta Pharmaceutica Sinica B. 2019;9(1):36-48.

6. Laouini A, Charcosset C, Fessi H, Holdich RG, Vladisavljević GT. Preparation of liposomes: a novel application of microengineered membranes-from laboratory scale to large scale. Colloids and Surfaces B: Biointerfaces. 2013;112:272-8.

7. Pan K, Luo Y, Gan Y, Baek SJ, Zhong Q. pH-driven encapsulation of curcumin in self-assembled casein nanoparticles for enhanced dispersibility and bioactivity. Soft Matter. 2014;10(35):6820-30.

8. Basnet P, Hussain H, Tho I, SkalkoBasnet N. Liposomal delivery system enhancesanti-inflammatory properties of curcumin. Journal of Pharmaceutical Sciences. 2012;101(2):598-609.

9. Peng S, Zou L, Liu W, Li Z, Liu W, Hu $X$, et al. Hybrid liposomes composed of amphiphilic chitosan and phospholipid: Preparation, stability and bioavailability as a carrier for curcumin. Carbohydrate Polymers. 2017;156:322-32.

10. Kumar N, Rai A, Reddy ND, Raj PV, Jain P, Deshpande P, et al. Silymarin liposomes improves oral bioavailability of silybin besides targeting hepatocytes, and immune cells. Pharmacological Reports. 2014;66(5):788-98.

11. Chen X, Zou LQ, Niu J, Liu W, Peng SF, Liu CM. The stability, sustained release and cellular antioxidant activity of curcumin nanoliposomes. Molecules. 2015;20(8):14293-311.

12. Patil YP, Jadhav S. Novel methods for liposome preparation. Chemistry and Physics of Lipids. 2014;177:8-18.

13. Hasan M, Ben Messaoud G, Michaux F, Tamayol A, Kahn CJF, Belhaj N, et al. Chitosan-coated liposomes encapsulating curcumin: study of lipid-polysaccharide interactions and nanovesicle behavior. Royal Society of Chemistry Advances. 2016;6(51):45290-304.

14. Yallapu MM, Jaggi M, Chauhan SC. $\beta$ Cyclodextrin-curcumin self-assembly enhances curcumin delivery in prostate 
cancer cells. Colloids and Surfaces B: Biointerfaces. 2010;79(1):113-25.

15. Zou L, Peng S, Liu W, Gan L, Liu W, Liang $\mathrm{R}$, et al. Improved in vitro digestion stability of (-)-epigallocatechin gallate through nanoliposome encapsulation. Food Research International. 2014;64:492-9.

16. Paramera EI, Konteles SJ, Karathanos VT. Microencapsulation of curcumin in cells of Saccharomyces cerevisiae. Food Chemistry. 2011;125(3):892-902.
17. Liu W, Liu W, Ye A, Peng S, Wei F, Liu $\mathrm{C}$, et al. Environmental stress stability of microencapsules based on liposomes decorated with chitosan and sodium alginate. Food Chemistry. 2016;196:396-404. 